\title{
Records of Chenopodiaceae in Asian Russia
}

\author{
M. N. Lomonosova \\ Central Siberian Botanical Garden of SB RAS, Zolotodolinskaya Str., 101, Novosibirsk, 630090, Russia. \\ E-mail:mlomonosova@mail.ru
}

Keywords: Chenopodiaceae, flora, habitat, Siberia.

Summary. Chenopodiastrum murale and Chenopodium probstii are recorded for the first time for the flora of Asian Russia, Suaeda arctica - for the flora of Siberia. Three species have been discovered in particular regions: Novosibirsk Oblast (Blitum virgatum), Buryatia Republic (Oxybasis micrantha) and Tyva Republic (Grubovia melanoptera).

\section{Флористические находки маревых (Chenopodiaceae) в Азиатской России}

\author{
М. Н. Ломоносова
}

Центральный сибирский ботанический сад СО РАН, ул. Золотодолинская, 101, г. Новосибирск, 630090, Россия

Ключевые слова: местообитание вида, Сибирь, флора, Chenopodiaceae.

Аннотация. Впервые для флоры азиатской России приводятся Chenopodiastrum murale и Chenopodium probstii, Suaeda arctica - для флоры Сибири. Три вида указываются впервые для флоры отдельных регионов Сибири: Новосибирской области (Blitum virgatum), Республики Бурятия (Oxybasis micrantha) и Республики Тыва (Grubovia melanoptera).

During a study of the Chenopodiaceae of Asian Russia, in addition to field work a large number of specimens were examined in various herbaria including TK and VLAD (acronyms according to Tiers 2017+). As a result, two species new for the flora of Asian Russia (Chenopodiastrum murale (L.) S. Fuentes, Uotila et Borsch and Chenopodium probstii Aellen) were found, and one species for the flora of Siberia (Suaeda arctica Jurtz. et Petrovsky). Three species are new for the flora of particular regions of Siberia: Novosibirsk Oblast (Blitum virgatum L.), Tyva Republic (Grubovia melanoptera (Bunge) Freitag et G. Kadereit) and Buryatia Republic (Oxybasis micrantha (Trautv.) Sukhor. et Uotila). An additional locality of the last species was also discovered in Primorsky Krai. Of these species Chenopodiastrum murale and Blitum virgatum are alien to the area, while the four other taxa are native elements. The taxonomy of Chenopodiaceae is considered in relation to recent molecular-phylogenetic studies (Kadereit, Freitag, 2011; Fuentes-Bazan et al., 2012).

All specimens collected by M. Lomonosova are stored in the Herbarium of the Central Siberian Botanical Garden SB RAS (NS).

Chenopodiastrum murale (L.) S. Fuentes, Uotila et Borsch (Chenopodium murale L.): "Russia, Primorsky Krai, Vladivostok, Akademgorodok, 1992, E. Rudyka s. n. (VLA)" [In Russian]. - This species is widely distributed in the Mediterranean area, North Africa, Caucasus and subtropical Asia, and as an alien in many other regions (Uotila 2001). C. murale was mentioned from many localities in the European part of Russia by Mosyakin (1996, 2012) but this is inconsistent with the opinion of 
Sukhorukov (2014) who noted that the range of this species comprises only Krasnodar Krai.

C. murale is characterized by having seeds with a prominent keel and dark-green leaves coarsely and irregularly toothed.

Chenopodium probstii Aellen: "Russia, [Tyva Republic] Tuva ASSR, Tes-Khem district, KholEzhu village, field road, N5045', E94²2', 06 IX 1989, M. Lomonosova, O. Zhdanova 69" [In Russian]; "Russia, Khakasia Republic, Shira district, Itkul' Lake, in a flower bed, 16 IX 2004, M. Lomonosova 578"; [In Russian] "Russia, Kamchatka Oblast, Koryak National Okrug, Karaginsk district, vicinity of Occora village, 14 VIII 1976, S. Kharkevich, T. Buch s. n." [In Russian] (VLAD); "Russia, Primorsky Krai, Shkotovo district, vicinity of Rechishche village, Sukhodol river mouth, saltwort annuals on a sandy seashore, $\mathrm{N} 43^{\circ} 12^{\prime}, \mathrm{E} 132^{\circ} 23^{\prime}$, 22 IX 2015, M. N. Lomonosova, P. G. Gorovoy 1248"; "Russia, Primorsky Krai, Amur Bay, Vladivostok, Akademgorodok, N43¹1', E131 ${ }^{\circ} 55^{\prime}, 23$ IX 2015, M. Lomonosova, I. Gorbunova 1249a" [In Russian]; "Russia, Primorsky Krai, Khasan district, Gamov Peninsula, Tretyakov Bay, among rocks on the beach, $\mathrm{N} 42^{\circ} 35^{\prime}, \mathrm{E} 131^{\circ} 13^{\prime}, 8$ X 2017 , M. Lomonosova 1415b" [In Russian]. - This species occurs as an adventive in Central Europe. Rare casuals are known from Egypt, North Korea and Australia (Dostálek, Jehlík, 2004). Recently C. probstii was mentioned for NW China (Mandák et al., 2016). There are two records for the European part of Russia: from Udmurtia (Mosyakin, 2012) and Kalmykia (Sukhorukov, 2014).

Chenopodium probstii is a member of a widely distributed polyploid complex C. album aggr. and was often misidentified as C. album L. C. probstii is clearly characterized by the leaves which are broadly ovate, thick, dark-green, with mostly doubly dentate basal lobes, and a purple coloration of the margin or throughout the blade, as well as dense inflorescences.

Suaeda arctica Jurtz. et Petrovsky: "Russia, Sakha (Yakutia) Republic, Namsky ulus, vicinity of Khamagatta village, solonchak with Salicornia, N62 ${ }^{\circ} 40^{\prime}$, E12941', 20 VIII 2012, M. N. Lomonosova, E. G. Nikolin 790" [In Russian]; "Russia, Sakha (Yakutia) Republic, Namsky ulus, north outskirts of Maimaga village, degraded solonchak, $\mathrm{N} 63^{\circ} 02^{\prime}$, E12931', 20 VIII 2012, M. N. Lomonosova, E. G. Nikolin 797” [In Russian]; "Russia, Sakha (Yakutia) Republic, Namsky ulus, vicinity of Tastakh vil- lage, patches of solonchak along the road, $\mathrm{N} 62^{\circ} 43^{\prime}$, E129 22', 21 VIII 2012, M. N. Lomonosova, E. G. Nikolin 807" [In Russian]; "Russia, Sakha (Yakutia) Republic, Khangalassky ulus, between Bulgunyakhtakh and Ulakhaan-An villages, patches of solonchak on permafrost mounds, N61 ${ }^{\circ} 19^{\prime}$, E128 $8^{\circ} 37^{\prime}$, 24 VIII 2012, M. N. Lomonosova, E. G. Nikolin 843" [In Russian]; "Russia, Sakha (Yakutia) Republic, Megino-Kangalassky ulus, 73-km-post along the Kolyma Tract, vicinity of Tumul village, farm road on solonchak, N62 ${ }^{\circ} 10^{\prime}, \mathrm{E} 130^{\circ} 38^{\prime}, 28$ VIII 2012, M. N. Lomonosova, E. G. Nikolin 878" [In Russian]. - Since its description in 1968, S. arctica was known for a long time only from the locus classicus on the shore of Chaunskaya Bay in Chukotka. In 1998 this species was collected by O. Mochalova on the shore of the Sea of Okhotsk (Lomonosova, 2008). During a field trip to Yakutia in 2012, it was found that $S$. arctica is distributed widely in saline localities of Central Yakutia where this diploid species occurs sympatrically with hexaploid $S$. corniculata (C. A. Mey.) Bunge s. str. with whom S. arctica was earlier confused.

In addition to the ploidy level, $S$. arctica clearly differs from $S$. corniculata by the pinkish color, compact inflorescences, smaller fruits, shape of perianth segments and the short adpressed leaves. That these taxa are also separate genetically was established on the basis of molecular-phylogenetic analysis (Brandt et al., 2015) and ISSR fingerprinting (Lomonosova et al., 2017). In these papers, plants collected in Yakutia were discussed under the preliminary name S. 'jacutica'. Whether Yakutian populations of $S$. arctica represent another taxon of subspecies rank should be the subject of further taxonomic research.

Blitum virgatum L. (Chenopodium foliosum (Moench) Asch.): "Russia, Novosibirsk Oblast, Karasuk village, on loan, 13 IX 2012, M. N. Lomonosova 927" [In Russian]. - This montane species is distributed from Himalaya through Central and Middle Asia to the Alps. As an established alien it occurs in Central Europe (Uotila, 2001) and the European part of Russia (Sukhorukov, 2014). In the Asian part of Russia it is a characteristic native element of the Altai-Sayan montane system. In Siberia $B$. virgatum has been mentioned as a rare alien from Buryatia (Sutkin, 2003), Khanty-Mansy Autonomous Okrug (Lomonosova, 2006), Magadan Oblast (Lysenko, 2008) and Irkutsk Oblast (Chepinoga et al., 2008). The explanation of this distribution pattern is the use of the species as an ornamental plant on account of 
its edible berry-like red fruits that produce mature seeds enabling dispersal from gardens.

Grubovia melanoptera (Bunge) Freitag et G. Kadereit (Kochia melanoptera Bunge): "Russia, Tyva Republic, Tes-Khem district, Sharanur Lake, Achnatherum splendens community, $902 \mathrm{~m}$ above sea level, N50²3', E9461', 04 IX 2013, M. Lomonosova 1007" [In Russian]; "Russia, Tyva Republic, Ovyursky district, vicinity of Ak-Chyraa village, steppe, N5070', E93²6', 05 IX 2013, M. Lomonosova 1023" [In Russian]; "Russia, Tyva Republic, Dzun-Khemchik district, vicinity of lime village, Achnatherum splendens community in the river valley, N5149', E91²47', 06 IX 2013, M. Lomonosova 1030" [In Russian]. - The sites in Tyva are located along the northern border of this Central Asian species ranging from eastern Kazakhstan and Kirgizstan to Central China, and Mongolia to easternmost Tadzhikistan (Grubov, 1966). In Russia G. melanoptera is distributed in southeastern Altai.

The genus Grubovia Freitag et Kadereit was recently established on the base of morphological and molecular-phylogenetic analysis and consists of three Central Asian annual species. Besides G. melanoptera, this genus includes G. krylovii (Litv.) Freitag et G. Kadereit (Kochia krylovii Litv.) and G. dasyphylla (Fisch. et C. A. Mey.) Freitag et G. Kadereit (Bassia dasyphylla (Fish. et C. A. Mey.) Kuntze). The main features of this genus are the unique leaf anatomy with a peculiar type of photosynthesis, and the separate, well supported clade in phylogenetic trees (Kadereit, Freitag, 2011). G. melanoptera is characterized by a peculiar tepal morphology of the fruiting perianth, with three tepals having wing-like outgrowths while the two others have a horn-like outgrowths. It should be pointed out that these markers were used until recently for delimiting the genus Kochia Roth (including plants with wing-like outgrowths) and Bassia All. (including plants with horn-like ones), although Scott (1978) has mentioned the limited taxonomic value of fruit characters in the subfamily Camphorosmeae. This has been confirmed by comprehensive analysis and is taken into account in the new classification (Kadereit, Freitag, 2011), in which Kochia is now congeneric with Bassia.

Oxybasis micrantha (Trautv.) Sukhor. et Uotila (Chenopodium micranthum Trautv.): "Russia, [Buryatia Republic] Buryat-Mongol ASSR, Kabansk aimak, vicinity of Temlyu village, along roads, 17 VII 1940, L. P. Sergievskaya s. n.” [In Russian] (TK); "Russia, Primorsky Krai, Nakhodka city district, vicinity of Avangard village, Vostok Bay, seashore, wet meadow at the river mouth with Phragmites australis, Salicornia perennans and Tripolium vulgare, N42 ${ }^{\circ} 4^{\prime}$, E13243', 19 VIII 2015, M. Lomonosova, I. Gorbunova 1227" [In Russian]. In Russia this Asiatic species sporadically occurs from the South Urals to the Far East, while only two localities are known east of Lake Baikal: in Zabaikalsk Krai and Primorsky Krai (Sukhorukov et al., 2013).

Chenopodium micranthum was described in 1868 and later cited in the literature only once by Trautvetter (1884). In herbarium collections it was often misidentified as Chenopodium urbicum L. or C. urbicum subsp. sinicum Kung et G. L. Chu. Recently Sukhorukov et al. (2013) assigned C. micranthum and C. urbicum subsp. sinicum to Oxybasis micrantha. The latter species differs clearly from O. urbica (L.) S. Fuentes, Uotila et Borsch by the exceptionally small seeds, spreading perianth segments in the fruit stage, and the elongated triangular-hastate and almost entire leaves.

\section{Acknowlegements}

The author is grateful to the herbarium curators and staff of TK and VLAD for their assistance during work with herbarium collections. Geoffrey H. Harper is thanked for the linguistic revision of the text. The study was carried out in the framework of the Scientific program № AAAA-A17-117012610055-3 of the Central Siberian Botanical Garden SB RAS and partially supported by the Russian Foundation for Basic Research (project No 15-29-02664).

\section{REFERENCES / ЛИТЕРАТУРА}

Brandt R., Lomonosova M., Weising K., Wagner N., Freitag H. 2015. Phylogeny and biogeography of Suaeda subg. Brezia (Chenopodiaceae/Amaranthaceae) in the Americas. Plant. Syst. Evol. 301(10): 2351-2375. DOI: http:// dx.doi.org/10.1016/ppees.2016.09.004

Chepinoga V. V. 2008. Chenopodiaceae Vent. In: Check-list of the vascular flora of the Irkutsk region. Ed. L. I. Malyshev. Publishing of Irkutsk State University, Irkutsk, 110-113 pp. [In Russian]. (Чепинога В. В. Chenopodiaceae Vent. // Конспект флоры Иркутской области (сосудистые растения) / Ред. Л. И. Малышев. Иркутск: Изд-во Иркутского гос. ун-та, 2008. С. 110-113). 
Dostálek J., Jehlik $\boldsymbol{V}$. 2004. Chenopodium probstii and Chenopodium missouriense: two North American plant species in the Czech Republic, Slovak Republic and neighbouring countries. Feddes Repertorium 115(5-6): 483-503.

Fuentes-Bazan S., Uotila P., Borsch T. 2012. A novel phylogeny-based generic classification of Chenopodium sensu lato, and a tribal rearrangement of Chenopodioideae (Chenopodiaceae). Willdenowia 42: 5-24. DOI: http:// dx.doi.org/10.3372.wi42.42101.

Grubov V. I. 1966. Plantae Asiae Centralis. Vol. 2. Nauka, Moscow-Leningrad, 135 pp. [In Russian]. (Грубов В. И. Растения Центральной Азии. Т. 2. М.-Л.: Наука, 1966. 135 с.).

Kadereit G., Freitag H. 2011. Molecular phylogeny of Camphorosmeae (Camphorosmoideae, Chenopodiaceae): Implications for biogeography, evolution of $\mathrm{C}_{4}$-photosynthesis and taxonomy. Taxon 60 (1): 51-78.

Lomonosova M. N. 2006. Chenopodiaceae. In: A manual for the identification of plants of the Khanty-Mansy Autonomous Okrug. Ed. I. M. Krasnoborov. Basko, Novosibirsk-Ekaterinburg, 68-71 pp. [In Russian]. (Ломоносова M. H. Chenopodiaceae. // Определитель растений Ханты-Мансийского автономного округа / Ред. И. М. Красноборов. Новосибирск-Екатеринбург: Баско, 2006. С. 68-71).

Lomonosova M. N. 2008. New data about distribution of some species of the families Chenopodiaceae and Poaceae in the Asian part of Russia. Turczaninowia 11, 4: 56-59 [In Russian]. (Ломоносова М. Н. Новые данные о распространении некоторых видов семейств Chenopodiaceae и Роасеае в азиатской России // Turczaninowi $a$, 2008. Т. 11, вып. 4. С. 56-59.

Lomonosova M. N., Nikonova D. E., Kutsev M. G., Dorogina O. V., Korolyuk A. Yu. 2017. Genetic differentiation in the polyploid complex of Suaeda corniculata (C. A. Mey.) Bunge in Eastern Asia. Russian Journal of Genetics 53(5): 596-605.

Lysenko D. S. 2012. Sinantropic flora of Magadan Region. SVNTS DVO RAS, Magadan, 111 pp. [In Russian]. (Лысенко Д. С. Синантропная флора Магаданской области. Магадан: изд-во СВНЦ ДВО РАН, 2012.111 с.).

Mandák B., Krak K., Vít P., Pavlíková Z., Lomonosova M. N., Habibi F., Lei W., Jellen E. N., Douda J. 2016. How genome size variation is linked with evolution within Chenopodium sensu lato. Perspectives in Plant Ecology, Evolution and Systematics 23: 18-32.

Mosyakin S. L. 1996. Chenopodium L. In: Flora Europae Orientalis Vol. 9. Ed. N. N. Tzvelev. Mir i Semya-95, St. Petersburg, 27-44 pp. [In Russian]. (Мосякин С. Л. Chenopodium L. // Флора Восточной Европы. Т. 9 / Ред. Н. Н. Цвелев. СПб.: Мир и семья-95, 1996. С. 27-44).

Mosyakin S. L. 2012. Chenopodium L. In: Conspectus Florae Europae Orientalis. Vol. 1. Eds. N. N. Tzvelev, D. V. Geltman. KMK Scientific Press, St. Petersburg-Moscow, 280-286 pp. [In Russian]. (Мосякин С. Л. Сhепороdium L. // Конспект флоры Восточной Европы. Т. 1. Ред. Н. Н. Цвелев, Д. В. Гельтман. СПб.-М.: Товарищество научных изданий КМК, 2012. С. 280-286).

Scott A. J. 1978. A revision of the Camphorosmoideae (Chenopodiaceae). Feddes Repertorium 89: 101-119.

Sukhorukov A. P. 2014. The carpology of the Chenopodiaceae with reference to the phylogeny, systematics and diagnostics of its representatives. Grif et K., Tula, 400 pp. [In Russian]. (Сухоруков А. П. Карпология семейства Chenopodiaceae в связи с проблемами филогении, систематики и диагностики его представителей. Тула: Гриф и К., 2014. 400 с.).

Sukhorukov A. P., Uotila P., Zhang M., Zhang H.-X., Speranskaya A. N., Krinitsyna A. A. 2013. New combinations in Asiatic Oxybasis (Amaranthaceae s. 1.): evidence from morphological, carpological and molecular data. Phytotaxa 144(1): 1-12.

Sutkin A. V. 2003. The new localities of Chenopodium foliosum (Chenopodiaceae) and Malva mauritiana (Malvaceae) in central Siberia. Turczaninowia 6, 1: 70-72 [in Russian]. (Суткин A. В. Новые местонахождения Сhenopodium foliosum (Chenopodiaceae) и Malva mauritiana (Malvaceae) в Центральной Сибири // Turczaninowia, 2003. Т. 6, вып. 1. С. 70-72).

Thiers B. 2017. Index Herbariorum: A global directory of public herbaria and associated staff. New York Botanical Garden, Bronx, NY. Available from: http://sweetgun.nybg.org/science/ih/ (Accessed 30 November 2017).

Trautvetter E. R. 1884. Incrementa florae phanerogamae rossicae. Fasc. III. Acta Horti Petropolitani 9: 1-220.

Uotila P. 2001. Chenopodium L. In: Flora Nordica Vol. 2. Ed. by B. Jonsell. The Bergius Foundatio, Stockholm. 4-31 pp. 